\title{
Historical Bibliography: \\ Its Role in Canadian Descriptive Bibliography
}

John A.Wiseman

HISTORICAL BIBLIOGRAPHY HAS ITS 'PURE' AND 'APPLIED' FORMS, AND when it is applied to descriptive bibliography, it performs an important and fundamental role. Before any further discussion, I should make clear my understanding of what is meant by historical bibliography. I may add that, in theory, it should only be necessary to reach agreement on the term 'historical' except that the word 'bibliography' itself has caused problems. The celebrated W.W. Greg fretted over it, concerned that it would be taken to mean only the compilation of bibliographies. ${ }^{1}$ If this problem still exists, and I think it does, it is due in part to the all too frequent use of the term 'bibliography' without qualification. I would suggest that when used alone it should mean the entire field of bibliographical activity only; when a particular aspect is under discussion, the qualifying adjective ('enumerative', 'analytical', 'textual', 'descriptive', 'historical') should always be in evidence to avoid any ambiguity.

Among the various types of bibliographical activity, the historical has a pervasive quality, underpinning much of the work in analytical, textual, and descriptive bibliography. It embraces all aspects of the book trade from the author to the dissemination of published materials in their various forms; it includes the development of papermaking, ink, typography, presses, bindings, illustration processes, copyright law and practice, libraries, readership, and also the printed word ${ }^{2}$ in its social context; in fact, historical bibliography frequently rubs shoulders with social and cultural history and with literary studies. In broad terms, acting in concert with analytical bibliography, it materially assists in establishing what Greg has termed the 'genetic origin'3 of the materials that constitute descriptive bibliographies.

Although Richard Landon is correct when he asserts that the emphasis in the past in Canada has been almost exclusively on enumerative bibliography, ${ }^{4}$ historical bibliography has not been entirely neglected. A handful of nineteenth-century publications might legitimately be regarded as early studies in Canadian historical bibliography, though it is unlikely that their authors would have perceived them as such. Samuel Dawson's Copyright in Books: An Inquiry into its Origin, and an Account of the Present State of the Law in Canada (Montreal: Dawson Bros., r882) is one example. Looking at 
periodical literature, E.C. Beaty's article entitled 'Novels', which appeared in Belford's Monthly Magazine (April I878), is exactly the sort of thing an historical bibliographer might research and write, as it deals with the dissemination of cheap novels.

Moving into the twentieth century, Canadian Bookman is a rich source of articles that fit the criteria of historical bibliography. E.J. Moore's discussion of the Methodist Book and Publishing House is a notable example..$^{5}$ might also mention Marie Tremaine's pamphlet entitled Early Printing in Canada (Toronto: Golden Dog Press, 1934) and H. Pearson Gundy's Early Printers and Printing in the Canadas (Toronto: Bibliographical Society of Canada, I957). There are, of course, others.

A search through the Papers of our own Society reveals a number of valuable contributions, but to avoid the sin of omission I shall not enumerate or describe them here. However, I think it would be in order to draw your attention to the fact that there are a number of studies contained in our annual offering that have added some 'features' to the 'almost blank' face of nineteenth-century historical bibliography, which was Douglas Lochhead's metaphorical assessment of the situation in $1971{ }^{6}$

It is interesting that certain non-bibliographical publications sometimes publish research that falls within the purview of historical bibliography. An example is Nina L. Edwards' article entitled 'The Establishment of Papermaking in Upper Canada,' which turned up not in the Papers of this Society but in Ontario History. ${ }^{7}$ All such research is grist for the descriptive bibliographer's mill, and evidence of ongoing endeavours may be found in the pages of Peter Greig's checklist published last year. ${ }^{8}$

In this connection it is worth noting that a number of standard works in Canadian historical bibliography have yet to be written. It is not my intention to make invidious comparisons, but there are some works of American, British, and French origin that would serve as ideal models. An English edition of L'Apparition du livre by Lucien Febvre and Henri-Jean Martin appeared in 1976. Its English title is The Coming of the Book: The Impact of Printing, 14501800 (London: NLB, 1976). This work is important, not because we would necessarily want to duplicate it, but because it suggests ways in which we might approach the history of the book in Canada. In the preface the authors state that its title could easily have been The Book in the Service of History. They go on to say that it was not their intention to write or rewrite a history of printing. 'We hope,' they say, 'to establish how and why the printed book was something more than a triumph of technical ingenuity.... In short we are hoping to prove that the printed book was one of the most effective means of mastery over the whole world.' Scaled down to a national level, it would be fascinating, and indeed novel, to attempt to apply such a concept to Canada. If you are at all doubtful, some of the ideas explored in this book are indicated by 
the chapter headings, of which the following are samples: 'The Book as a Commodity,' 'The Geography of the Book,' 'The Book as a Force for Change.'

Another work that has added a new dimension to historical bibliography is Richard Altick's The English Common Reader: A Social History of the Mass Reading Public, 1800-1900 (Chicago: University of Chicago Press, 1963). What inakes this work particularly significant is that its author has, through the exploration of religion, education, literacy, mechanics' institutes, public libraries, periodicals and newspapers, and the book trade of the period, told the story of 'a revolutionary social concept: that of the democracy of print.' This should quite readily translate into Canadian terms.

A definitive history of Canadian libraries is sorely needed. Elizabeth Homer Morton was, I understand, working on such a project at the time of her death. It was to be an expansion of her master's thesis. It should not be allowed to fall by the wayside, and we can only hope that some enterprising researcher will have the desire and the opportunity to complete this important work. If a model is needed, Thomas Kelly's A History of Public Libraries in Great Britain, 1845-1975 (London: The Library Association, 1977) will serve admirably.

I wish to mention one other work which, I think, deserves to be emulated in this country. I am referring to Frank Luther Mott's four-volume history of American magazines, ${ }^{10}$ a superlative piece of scholarship. Some work has been done on Canadian magazines, but as far as I can tell, nothing on the scale or depth of Mott's work has been attempted so far. ${ }^{11}$

I now wish to say something about the sources of Canadian historical bibliography. It was the historian John Bartlet Brebner who coined the phrase 'North Atlantic Triangle' as the title for his book which discusses the interplay of Canada, the United States, and Great Britain. ${ }^{12}$ Brebner makes it clear that he means more than merely international relations of the political kind. He is interested in the 'common activities' of the millions who moved about quite freely over the North American continent settling the land, harvesting its resources, competing in the market place, and in the process creating 'the unique North American standard and pattern of living.' ${ }^{13} \mathrm{He}$ adds that none of this can be explained in North American terms only; the influence and participation of Great Britain in the affairs of North America make the mother country the important third side of the triangle. ${ }^{14}$ If you are wondering what any of this has to do with historical bibliography, the simple answer is that this same interplay of three nations underlies much of what we may learn about the history of the printed word in Canada. The convoluted story of Canadian copyright exemplifies this concept.

This so-called 'triangle' is something of a mixed blessing for historical bibliographers. On the one hand it opens up a fairly broad range of primary and secondary sources which enable us to bring our historical problems into better perspective, both at the national and international levels. On the other 
hand, an otherwise seemingly simple problem may become quite complex when Brebner's North Atlantic thesis is applied to it. Nevertheless, it would be unwise, for example, to consider Canada's publishing history without some reference to the book trade in the United States and Britain; any study of reading habits and taste must take account of aesthetic, social, moral, religious, and literary influences from abroad; similarly, technological changes relating to print must at some point be viewed from an international stance, if only to isolate original Canadian contributions to this sphere of endeavour. As a consequence, the historical bibliographer must delve into an unusually mixed bag of tricks to find his information. In addition, he must frequently display a fair measure of ingenuity.

This is illustrated quite clearly in the case of publishers' archives which represent an important primary source. Unfortunately, as Richard Landon has pointed out, we cannot assume that they exist, and when they do, that they are organized in such a way as to be readily available and useful to the historical bibliographer. Ontario is in a particularly bad situation because of the Toronto fire of 1904 that destroyed all prior records. ${ }^{15}$ When publishers' records $^{16}$ are non-existent, contemporary books, magazines, and newspapers must be culled for advertisements, announcements, and any other scraps of evidence that might serve as acceptable substitutes. For those with time and tenacity, searches through general archival collections can also be fruitful.

Economic and political issues sometimes have a direct bearing upon bibliographical phenomena; again, copyright is a prime example. This suggests the vital importance of government publications, especially those of a legislative nature. To be more specific, matters of trade, transportation, communications, and the like, are invariably the concern of governments and also affect many aspects of publishing; research into the early history of newspapers, for example, would have to include a perusal of the Deputy Postmaster-General's reports, as the post office played a part in the dissemination of the periodical press.

Social histories, church histories, educational studies, contemporary and modern; dictionaries, almanacs, and settlers' guides; biographical works and anecdotal histories - all contain many clues that may be of value to the historical bibliographer. Searching this material is slow, painstaking work that requires sound background knowledge and judgement in deciding what is valid and what is not. Making the information available to the descriptive bibliographer is another matter.

A good cross-section of problems facing descriptive bibliographers may be found in the pages of Canadian Notes e Queries, many of which are of an historical nature. A title page bears the date 1815 , but the work was not actually published until 1826- why was its publication withheld for so many 
years? Note is taken of a reference to a fugitive pamphlet that is of significant bibliographical interest - what is it, and where is it? Who is the author of an anonymous nineteenth-century book?

In William Morley's excellent bibliographical study of Major John Richardson, the annotations appended to the entry for Hardscrabble extend over more than three pages and display a remarkable range of historical facts about the work. It is evident from the high standards achieved in descriptive bibliographies of this calibre that good use has been made of the tools and resources of historical bibliography. What is uncertain is the extent to which descriptive bibliographers carry out their own historical investigations rather than seek out colleagues whose interests lie principally in the historical sector.

Attention has been drawn to the solitary nature of descriptive bibliography as presently practised. ${ }^{17}$ It would be smugly satisfying to believe that such solitude springs from self-sufficiency: that the rather idealistic requirements for practising descriptive bibliography as set out by Fredson Bowers have all been met $^{18}$ but this is not necessarily the case. Admittedly, there are among us a number of experienced descriptive bibliographers who are extremely knowledgeable in publishing and printing history and have mastered analytical techniques, but even they cannot take the additional time necessary to make their knowledge complete and encyclopedic if they are to get on with the business of developing descriptive bibliographies. It would appear that the main reason for the isolation of many is not their self-sufficiency so much as the absence of a highly visible community of historical bibliographers with whom they could relate. ${ }^{19}$ Presumably, communicating among themselves only partly satisfies the needs of descriptive bibliographers.

I should like to make a few suggestions that may remedy this situation. It seems important that the existing corpus of publication in historical bibliography should become more widely known and accessible. A simple checklist, perhaps followed in time by a full dress descriptive bibliography, would be a good start. In addition, I would recommend bringing together and publishing those articles which have appeared in what I have termed 'non-bibliographical' publications as a suitable complement to the Papers of this Society. Worthwhile monographs which are difficult to acquire should be candidates for reprinting.

We need to identify the labourers in the field of historical bibliography. Peter Greig's valuable checklist of bibliographical research would assist enormously if future editions were organized in such a way so as to emphasize the broad fields of bibliographical endeavour rather than simple subjects; such a grouping would also identify various types of bibliographers.

In 1972, the editor of Canadian Notes $\uplus$ Q Queries questioned the need for the publication because of the lack of response. Fortunately, he was not 
discouraged, and it still appears from time to time. I would suggest that we give the editor all the support he deserves to ensure that $C N \Theta Q$ continues to appear, perhaps more frequently and with an increase in the number of contributors.

My last recommendation is that we should organize a symposium devoted entirely to Canadian historical bibliography. Until the whole field is brought into focus and some attempt is made to rationalize activity within it, it will remain extremely difficult to measure our success and distinguish aspects still in need of attention.

It was Roy Stokes who observed the tendency to rely upon 'small snippets here, there and everywhere ${ }^{\prime 20}$ to provide the historical background for various bibliographical undertakings. That was in 1974, but the situation does not seem to have altered very much. As a consequence, it is important that we delay no longer and attempt to synthesize the fragmented history of the printed word in Canada. If successful, it would benefit many segments of the bibliographical community, but none more than the descriptive bibliographer. 


\section{Notes}

I. W.W. Greg, 'What is Bibliography?' in Collected Papers (Oxford: Clarendon Press, I966), p. 77.

2. I have used 'printed word' in preference to 'book' to include serial publications.

3. Greg, op. cit., p. 76.

4. Richard G. Landon, 'Subject Bibliography - Literature in English,' in National Conference on the State of Canadian Bibliography, Vancouver, Canada, May 22-24, 1974: Proceedings (Ottawa: National Library, 1977), p. I7I.

5. E.J. Moore, 'Canada's First Publishing House: A History and an Appreciation,' Canadian Bookman (January 1919): 7I-74.

6. Douglas Lochhead, 'Nineteenth-Century Canadian Bibliography: To the Land Behind,' Papers of the Bibliographical Society of Canada Io (I97I): $5 \mathrm{I}$.

7. Ontario History 39 (1947): 63-74.

8. Peter Greig, Canadian Bibliographical Work in Progress: A Preliminary Subject Inventory (Ottawa: National Library, 1978).

9. Richard Altick, The English Common Reader, p. I. So far I have made no mention of a history of publishing, the reason being that such a work, from the pen of George Parker, is imminent.

Io. Frank Luther Mott, A History of American Magazines (Cambridge, Mass.: Harvard University Press, I957), 4 vols.

II. Mott traces the history of the magazines from every conceivable angle: format, content, subject and reader appeal, contributors, circulation, advertising, and so on. The difficulty with Canadian magazines would be finding all of them in sufficient quantities to allow for an equally searching analysis, as some are fugitive, to say the least.

I2. John Bartlet Brebner, North Atlantic Triangle: The Interplay of Canada, the United States and Great Britain (New York: Columbia University Press, 1945).

13. Ibid., p. xi.

I4. Ibid.

I5. Landon, op. cit., p. I83. The Metropolitan Toronto Central Library has a collection of nineteenth-century publishers' catalogues which brings some alleviation to this particular problem.

I6. This includes those records that pertain to the publishing of newspapers and magazines as well as books.

I7. William Morley, 'Report on the National Conference on the State of Canadian Bibliography,' Papers of the Bibliographical Society of Canada I3 (1974): 6.

18. Fredson Bowers, Principles of Bibliographical Description (N.Y.: Russell \& Russell, I962), p. I4. He suggests that the descriptive bibliographer should be an expert in the history of printing and publishing as well as in analytical techniques.

I9. I am extremely grateful to William Morley for his illuminating remarks on the problems of the Canadian descriptive bibliographer.

20. Roy B. Stokes, 'Conclusion,' in National Conference on the State of Canadian Bibliography, Vancouver, Canada, May 22-24, 1974: Proceedings (Ottawa: National Library, I977), p. 454. 
